\title{
The effect of landscape on functional connectivity and shell shape in the land snail Humboldtiana durangoensis
}

\author{
Benjamín López ${ }^{1}$, Omar Mejia ${ }^{\text {Corresp., } 1}$, Gerardo Zúñiga ${ }^{1}$ \\ ${ }^{1}$ Laboratorio de Variación Biológica y Evolución, Departamento de Zoología, Escuela Nacional de Ciencias Biológicas, Instituto Politécnico Nacional, \\ Mexico City, Mexico \\ Corresponding Author: Omar Mejia \\ Email address: homarmejia@hotmail.com
}

The populations of Humboldtiana durangoensis have experienced a drastic reduction in the effective population size; in addition, the species is threatened by anthropogenic activities. For the aforementioned, landscape genetics will serve as a tool to define the potential evolutionarily significant units (ESU) for this species. To complete our objective, we evaluated the effect of cover vegetation and climate on the functional connectivity of the species from the LGM to the present as well as the effect of climate on shell shape. Partial Mantel tests, distance-based redundance analysis and a Bayesian framework were used to evaluate connectivity. On the other hand, geometric morphometrics, phylogenetic principal component analysis and redundancy analysis were used for the analysis of shell shape. Our results suggest that the suitable areas have been decreasing since the LGM; also, vegetation cover rather than climate has influenced the genetic connectivity among land snail populations, although temperature had a high influence on shell shape in this species. In conclusion, vegetation cover was the main factor that determined the functional connectivity for the land snail; however, local selective pressures led to different phenotypes in shell shape that allowed us to postulate that each one of the previously defined genetic groups must be considered as a different ESU. 
1

2

3

4

5

6

7

8

9 10

11

12

13

14

15

16

17

18

19

20

21

22

23

24

25

26

27

28

29

30

31

32

33

34

35

36

37

38

39

40

41

42

43

44

45

46

\section{The effect of landscape on functional connectivity and shell shape in the land snail Humboldtiana durangoensis}

Benjamin López ${ }^{1}$, Omar Mejía ${ }^{1 *}$ and Gerardo Zúñiga1

${ }^{1}$ Laboratorio de Variación Biológica y Evolución, Departamento de Zoología, Escuela Nacional de Ciencias Biológicas, Instituto Politécnico Nacional, México

Corresponding author: homarmejia@hotmail.com; hmejiag@ipn.mx

(1)

(1)

13

15

(1)

17

9

.

(26

.

(3)


47

48

49

50

51

52

53

54

55

\section{Abstract}

The populations of Humboldtiana durangoensis have experienced a drastic reduction in the effective population size; in addition, the species is threatened by anthropogenic activities. For the aforementioned, landscape genetics will serve as a tool to define the potential evolutionarily significant units (ESU) for this species. To complete our objective, we evaluated the effect of cover vegetation and climate on the functional connectivity of the species from the Last Glacial Maximum (LGM) to the present as well as the effect of climate on shell shape. Partial Mantel tests, distance-based redundance analysis and a Bayesian framework were used to evaluate connectivity. On the other hand, geometric morphometrics, phylogenetic principal component analysis and redundancy analysis were used for the analysis of shell shape. Our results suggest that the suitable areas have been decreasing since the LGM; also, vegetation cover rather than climate has influenced the genetic connectivity among land snail populations, although temperature had a high influence on shell shape in this species. In conclusion, vegetation cover was the main factor that determined the functional connectivity for the land snail; on the other hand,the different phenotypes in shell shape allowed us to postulate that each one of the previously defined genetic groups must be considered as a different ESU. 
93

94

95

96

97

98

99

100

101

102

103

104

105

106

107

108

109

110

111

112

113

114

115

116

117

118

119

120

121

122

123

\section{Introduction}

Species dispersal can be affected not only by essential processes (e.g., the movement, mating, and reproductive fitness of the individuals) but also by ecological and topographical factors (e.g., abiotic variables, land cover, line features and landforms) associated with the landscape (Manel et al. 2003; McRae et al. 2008). Especially in land snails, dispersal is a process that is highly dependent on a set of variables associated with the landscape, such as climate and vegetation cover, which represent a high physiological cost for the snail (Dörge et al. 1999; Schweiger et al. 2004; Hylander et al. 2005; Aubry et al. 2006). Thus, in a heterogeneous landscape, the differentiation between populations may be increased not only by the historical events and microevolutionary factors but also by the ecological and topographical factors that determine the habitat or structural connectivity (McRae 2006; McRae et al. 2008; Bell et al. 2010).

Due to their low vagility, patchy distribution and preference for particular microhabitats (Dörge et al. 1999; Hylander et al. 2005; Aubry et al. 2006), land snails are excellent models for exploring the effects of landscape on the movement of individuals among suitable patches, or in other words, on the functional connectivity (Tischendorf and Fahrig 2000). The effect of the Pleistocene climate changes on the phylogeographical structure and demographic history of land snails has been widely documented (Ross 1999; Haase et al. 2003; Davison and Chiba 2006; Holland and Cowie 2007; Dépraz et al. 2008; Guiller and Madec 2010); as well as changes in vegetation cover that have caused a decline in abundance and species density (Hylander et al. 2004). However, neither the effect of vegetation cover nor the effect of the climate on functional connectivity have been explored yet.

The snails of the genus Humboldtiana represent a group of nearly 60 species that have an insular distribution in the mountainous regions from South Texas and New Mexico to Central Mexico (Thompson 2006, Mejía and Zuñiga 2007). Many species have very small ranges, with the exception of three species that are widely distributed (Mejía et al. 2018). H. durangoensis is distributed in the Madrense Centro ecoregion of the Sierra Madre Occidental in Durango state, mainly in cold temperate forests in an 
124 altitudinal gradient ranging from 1600 to $2800 \mathrm{~m}$ asl. This vegetation community has

125 historically been exploited in Durango state and has also experienced droughts and

126 fires that have led to fragmentation and habitat loss (Aragón-Piña et al. 2010). For these

127 reasons, forest loss has turned into a global conservation issue due to its effect on

128 biodiversity (Fahrig 2003).

129 Conservation efforts in several countries have traditionally been focused on

130 "surrogate" species, which can create the umbrella effect for other sympatric species

131 and, at the same time, serve to attract attention and funding (Caro and O'Doherty

132 1999). Illustrative examples of this situation in Mexico are the efforts to recover the tiny

133 vaquita porpoise (Phocoena sinus) and the Mexican wolf (Canis lupus baileyi).

134 Nevertheless, very few efforts have been conducted to preserve "non-charismatic

135 species" such as land snails. In fact, none of the nearly 1500 species of native land

136 snails that occur in Mexico (Thompson and Hubert 2011) are included in the Mexican

137 law for endangered species or in the IUCN Red List, a situation that highly contrasts

138 with European land snails (Cuttelod et al. 2011); at the same time, few studies of the

139 phylogeographic structure or population genetics have been performed with Mexican

140 land snails (López et al. 2017; López et al. 2019).

141 On the other hand, while there is a lack of agreement on how to define an

142 evolutionarily significant unit (ESU) (but see the review in Fraser and Bernatchez 2001),

143 we agree with those proposals that suggest that ESUs must include genetic, ecological

144 and morphological differentiation (Crandall et al. 2000) that reflect the adaptive

145 distinctiveness. Previous papers have evaluated the population genetics and

146 phylogeographic structure of $H$. durangoensis in the Madrense Centro region using

147 microsatellite DNA markers and mitochondrial and nuclear DNA (López et al. 2017;

148 López et al. 2019). The microsatellite analysis recovered seven genetic groups and

149 signals of a strong genetic bottleneck in the populations, while the mitochondrial and

150 nuclear DNA sequences found three main genetic groups that also showed signals of

151 drastic reduction in the effective population size.

152 To evaluate the effects of vegetation cover and local climatic variables on the

153 genetic differentiation of the snail $H$. durangoensis, we analyzed the functional

154 connectivity in three temporal frames: the last glacial maximum $(21,000$ years bp), the 
155 middle Holocene (6000 years bp) and the present. In addition, we evaluated the effect

156 of the climate on shell size and shape using phylogenetic comparative methods.

157 Despite the lack of agreement regarding the effects of the climate on shell traits, a

158 strong relationship between the phenotype, genetic variation and climate would be

159 expected (Dowle et al. 2015), because land snails as other groups with low vagility and

160 dispersal abilities, tend to develop local morphological adaptations due to restrictive

161 gene flow (Fitzpatrick 2012; Pfenninger and Posada 2002). Both approaches together

162 will allow us to postulate the ESU for this land snail in the Sierra Madre Occidental in

163 Western Mexico.

164 Methodology

165 Resistance surfaces

166 The geographic centroids of each one of the seven genetic groups of $H$. durangoensis

167 previously defined by microsatellite loci by López et al. (2017) were used to determine

168 the effect of the landscape on functional connectivity (Fig. 1). Whereas the landscape

169 can include a large number of variables, in the present work, we followed two

170 approximations to evaluate the functional connectivity between snail populations. The

171 first was to use an approximation of the Grinnellian niche defined from a set of

172 bioclimatic variables (Bell et al. 2010; Ortego et al. 2012; Poelchau and Hamrick 2012);

173 the second was to analyze the effect of vegetation cover, because it is known that it

174 affects the dispersion of terrestrial snails (Labaune and Magnin 2002; Armbruster et al.

175 2007; Ström et al. 2009; Edworthy et al. 2012; Kappes et al. 2009), especially in

176 mountain populations where periods of glaciation and deglaciation promoted the

177 contraction and expansion of vegetation cover (Armbruster et al. 2007). In both cases,

178 the different models were generated for three different time frames, including the current

179 period and two time periods representing the extreme conditions experienced during the

180 late Quaternary: the middle Holocene (6000 years bp), which was warmer and wetter

181 than the present, and the last glacier maximum (LGM), which was characterized by dry

182 and colder climates (21,000 years bp).

183 To reduce the error in the parameterization, validation, and comparison of the

184 models (Barve et al. 2011), the available geographic space for the taxon (M) was

185 defined as the Ecoregion Madrense Centro (González- Elizondo et al. 2013). Grinnellian 
186 niche models were constructed with the 19 climatic variables available in WorldClim

187 (Hijmans et al. 2005) and the 18 climatic and topographic variables available in

188 ENVIREM (Title and Bemmels 2018). The models were made at a resolution of 30 arc-

189 seconds, but in the case of the last glacial maximum (LGM), the variables were used at

190 their native resolution of 2.5 minutes, and a bilinear interpolation was performed to

191 decrease the resolution to 30 arc-seconds with the disaggregate function of the raster

192 library ver. 2.6-7 in R (Hijmans 2017). The atmospheric circulation model used was the

193 MPI-ESM-P, since it has shown better performance with respect to other models of

194 circulation (Tang et al. 2017). The bioclimatic variables were clipped to the geographic

195 space with the crop and mask functions of the raster library ver. 2.6-7 in R (Hijmans

196 2017).

197 Species niche model

198 The environmental suitability areas were defined by a maximum entropy algorithm

199 (MAXENT v. 3.2.19, Phillips et al. 2006) from 28 records of $H$. durangoensis available in

200 museums and our own collections. We selected this algorithm because it produces

201 reliable results even with a small quantity of data (Elith et al. 2006; Heikkinen et al.

202 2006; Hernandez et al. 2006). In a preliminary analysis, the 19 WorldClim and 18

203 ENVIREM variables were included with the default parameters and log output to

204 minimize the correlation and maximize their contributions to the model. The relative

205 importance of each variable was determined from its percentage of contribution and for

206 the loss of predictive power when each variable was excluded using a jackknife test. In

207 addition, to select those variables with correlation coefficients lower than 0.6,

208 environmental information was extracted from each geographic point, and a Pearson

209 correlation test was performed with the function corr.test in the psych library of $R$

210 (Revelle 2018). Thus, the geographic distribution model was obtained with the selected

211 variables and assumed 10,000 pseudoabsence points separated by one kilometer from

212 the presence records (Barbet-Massin et al. 2012). The statistical evaluation of the

213 model was carried out in 10 repetitions and the data were partitioned into $75 \%$ for

214 training and $25 \%$ for evaluation with a logistical output. The predictive power of the

215 model was evaluated using a partial ROC test with 100 bootstrap replicates (Barve 
216 2008). Finally, the suitability area available for the species in each temporal frame was

217 estimated with the DEM surface tools in ArcGIS 10.

218 Vegetation models

219 The random forest (RF) classification algorithm was used to obtain the modeled

220 vegetation cover (Breiman 2001). This method categorizes a set of data based on the

221 classification and regression of the trees from a bootstrap analysis (Breiman 2001). The

222 INE-INEGI (1997) vegetation cover map was used as an input file. Because this

223 classification contains many vegetation types for the Madrense Centro ecoregion, prior

224 to the analysis, the vegetation types were reclassified into five categories based on the

225 ombrothermal horizons of the Sierra Madre Occidental (Macías-Rodríguez et al. 2017):

226 (1) temperate forests, (2) cold temperate forests, (3) grasslands, (4) tropical forests and

227 (5) drylands. The model was trained to take into account the variables sets of BIOCLIM

228 and ENVIREM and to select only those that explained more than $50 \%$ of the variation

229 based on the mean decrease accuracy criterion; these models were made with the

230 randomForest 4.6-14 library in $\mathrm{R}$ (Breiman 2001).

231 Isolation by resistance

232 To evaluate the resistance of the landscape between the genetic groups, the resistance

233 isolation model (IBR) was implemented in CIRCUITSCAPE 3.4.2 (McRae 2006). This

234 method produces a resistance/conductance matrix between the pairs of sites that are

235 obtained by assigning an arbitrary resistance/conductance value per pixel

236 corresponding to the relative resistance of the landscape to the genetic flow. The result

237 was a resistance value that depended on the distance between the localities, the

238 number of possible pathways and the heterogeneity of the landscape (McRae 2006).

239 The following resistance values were assigned to the forest structure: 60 (cold

240 temperate forests), 110 (temperate forests), 200 (grasslands), 300 (tropical forests) and

241360 (drylands).

$242 \quad$ For the surface derived from the niche modeling, resistance values were

243 assigned considering five symmetrical categories defined by the range between the

244 minimum training presence (MTP) and the highest suitability value obtained by the

245 Maxent model. The values were assigned with the ifelse and raster $\mathrm{R}$ libraries (Hijmans

246 et al. 2005), and three different approaches were used to evaluate the relationship 
247 between the paired $F_{S T}$ values among the seven genetic groups (López et al. 2017) and 248 resistance values. Three matrices were considered in this analysis: the genetic paired 249 distances, the log10-transformed Euclidean geographical distances, and the paired 250 resistance distances obtained from CIRCUITSCAPE for the two evaluated resistance 251 surfaces (climate and vegetation). In the first approximation, the Mantel partial test was 252 used to evaluate the effects of the two variables while controlling for the effect of a third.

253 The significance of the partial correlation of the Mantel test was obtained by 1000 254 random permutations using the partial.mantel.test function of the NFC library (Bjørnstad 255 2013). In the second approach, a distance-based redundancy analysis (dbRDA) was 256 used in the vegan 2.5 library (Oksanen et al. 2013) considering the genetic distances, 257 geographic distances, and the effect of vegetation cover, as well as the effect of the 258 climatic distances on the mean of the resistance values (Noguerales et al. 2016). The 259 characterization of the environmental space was performed with the randomPoints 260 function in $\mathrm{R}$ that generated 1000 random geographic points and with the extract 261 function to obtain the climatic point value per site. Then, the main function in $\mathrm{R}$ was 262 used to perform the PCA, and later, the dist function in R was used to obtain the 263 eigenvalues of the environmental distances for the first three components considering 264 only the loadings of the geographic points corresponding to the genetic groups; finally, 265 the significance of the dbRDA was evaluated with the anova.cca function in R. Lastly, in 266 the third approach, given that in the two previous analyses the climate component was 267 not significant (see Tables 1 and 2), we only evaluate the effects of geography (G), 268 vegetation cover $(E)$ and both $(G+E)$ on functional connectivity through a Bayesian 269 framework implemented in the SUNDER 0.0.4 library (Botta et al. 2015). The algorithm 270 implemented in SUNDER assumed that the covariance of the allelic frequencies among 271 the populations would decrease as a function of the geographical and environmental 272 distances (Botta et al. 2015). Thus, to estimate the effect of the set of $G$, E, and G+E 273 variables, 10 independent chains with $10^{7}$ iterations and sampling every 1000 steps 274 were used with uniform priors with large upper bounds (Botta et al. 2015).

\section{Shell morphometrics}

276 A total of 129 shells of $H$. durangoensis adults from the seven genetic groups used by 277 López et al. (2017) were analysed: Las Peñas (20 shells), El Salto (8 shells), Progreso 
278 (3 shells), Topia (7 shells), Potrero (46 shells), Los Herreras ( 25 shells) and Guanaceví 279 (20 shells). The shape of the shell was obtained using two approaches: a classical 280 approach that assumed four linear shell measurements (height, $\mathrm{SH}$; width, SW; 281 aperture height, $\mathrm{AH}$; maximum aperture width, $\mathrm{AW}$ ) obtained with a digital micrometer 282 with an accuracy of $0.01 \mathrm{~mm}$; in addition, globosity ( $\mathrm{G}=\mathrm{SH} / \mathrm{WD})$, spiral height ( $\mathrm{SP}=\mathrm{SH}-$ $283 \mathrm{AH}$ ) and shell volume (V) were calculated (Fig. S1). These variables were transformed $284 \log 10$ transformed to remove the size effect following the method described by 285 Mosimann (1970). Finally, the eigenvalues of the mean and the centroid values for each 286 one of the genetic groups were recovered from a principal component analysis (PCA)

287 for posterior analysis (Harigan et al. 1979). On the other hand, the shell shape was 288 evaluated from 11 landmarks according to Mumladze et al. (2013) (Fig. S1). Following 289 the method proposed by Kistner and Dybdahl (2013), a total of five photos were taken 290 per individual to eliminate the error associated with the orientation. The $X / Y$ coordinates 291 were digitized in TPSDIG ver 2.12 (Rohlf 2008). The average shape per genetic group 292 and the deformation grids were obtained from a generalized Procrustes analysis (GPA) 293 in order to visualize changes in the shape of the shell with the gpagen function 294 implemented in geomorph 3.0.7 (Adams et al. 2019). To eliminate the phylogenetic 295 effect on the variation in shell shape, a phylogenetic principal component analysis 296 (pPCA) was performed considering the shell shape of both, classical and geometric 297 morphometrics approaches and a tree based on distances generated from $\mathrm{F}_{\text {ST }}$ values 298 with the function phyl.pca in phytools (Revell 2012); additionally, the deformation grids 299 of the average shell shape of the genetic groups were ploted in the phylomorphospace 300 with the plotGMPhyloMorphoSpace function implemented in Geomorph . Lastly, to 301 determine whether there was a relationship between the shell shape and environmental 302 conditions, a redundancy analysis (RDA) was performed considering the three matrices 303 generated (means and centroid values for each one of the seven genetic groupscas well as the average shape obtained from the geometric morphometrics analysis) with 305 the rda function following the method proposed by Borcard et al. (2018) in the vegan 306 library ver 2.5 (Oksanen et al. 2013).

\section{Results}


308 Six variables made the greatest contribution to the model of the potential distribution:

309 isothermality (Bio3), the minimum temperature of the coldest month (Bio6), the

310 precipitation of the wettest month (Bio 13), the precipitation of the driest month (Bio 14),

311 the precipitation of the coldest month (Bio 19), and the climatic humidity index. For the

312 potential vegetation model, 11 variables were selected: isothermality (Bio 3),

313 temperature seasonality (Bio 4), the annual temperature range (Bio 7), the annual

314 precipitation (Bio 12), the driest month precipitation (Bio 13), the seasonality of

315 precipitation (Bio 15), the coldest quartile precipitation (Bio 19), the average monthly

316 evapotranspiration potential of driest quarter (PETDriestQuarter), the monthly variability

317 in evapotranspiration potential (PETseasonality), the average monthly

318 evapotranspiration potential of the warmest quarter (PETWarmestQuarter), and the

319 average evapotranspiration potential of the wettest quarter (PETWettestQuarter).

320 Environmental suitability and vegetation models

321 The results obtained for the modeling of the distribution area of $H$. durangoensis in the

322 Madrense Centro region showed that the models constructed for the three temporal

323 frames were satisfactory $(P=0)$. In general, our findings suggested that the areas of

324 environmental suitability had decreased considerably in the last 21,000 years (38197

$325 \mathrm{~km}^{2}$ or $28.5 \%$ of the total area in the LGM, $32945 \mathrm{~km}^{2}$ or $24.5 \%$ in the mid Holocene and

$32623620 \mathrm{~km}^{2}$ or $17.6 \%$ in the current). Our findings show that at present, the areas with

327 high probability of occurrence are restricted to the northern portion of the distribution

328 area (Fig. 1). The model of vegetation cover generated from the current vegetation map

329 with random forest showed that the estimated success rate was $76.77 \%$ for the LGM,

$33077.48 \%$ for the Middle Holocene and $75.57 \%$ for the current period (Table S1). In

331 addition, in the last 21,000 years, a variation in the coverage area of each plant

332 community was estimated, and the temperate forests increased the most, while the

333 grasslands decreased the most (Table S1, Fig. S2).

334 Resistance and functional connectivity

335 The maps generated by CIRCUITSCAPE considering the structure of the vegetation

336 cover suggested that the connectivity routes between the $H$. durangoensis genetic

337 groups in the Central Madrense region have changed little in the last 21,000 years,

338 although in the actual period, the areas of high resistance are larger compared to those 
339 in the LGM (Table 1, Fig. S2). The resistance surface from the environmental suitability 340 models for the Mantel test and Mantel partial tests were not significant (Table 2, Fig.

341 S3). On the other hand, when considering the effects of vegetation cover, the Mantel

342 test between the values of $\mathrm{F}_{\mathrm{ST}}$ and vegetation cover was once again not significant in

343 any of the three time frames; however, the Mantel partial tests yielded significant

344 correlations when controlling for the effects of geography and vegetation cover in the

345 three time periods (Table 2). In the case of the redundancy analysis, the marginal tests

346 for the three time frames showed a significant association between the genetic

347 differentiation and geographic distance, explaining $24.26 \%$ of the variance, but were not

348 significant when the resistance distances generated from the vegetation cover or from

349 the climatic variables were considered (Table 3). In contrast, in the conditional tests as

350 in the Mantel partial test, a relationship was again observed with the structure of the

351 vegetation cover but not with that of the climate (Table 3 ). With respect to the results

352 generated by SUNDER, when the climatic component was no longer considered, it was

353 observed that during the LGM, it was the geographic component that best explained the

354 variation, while for the Middle Holocene and the actual period, both the geographic

355 component and the vegetation cover were important (Table 4).

356 Variation in shell size and shape

357 The values estimated from the morphometrics classical approach allow us to establish

358 that the populations located in the north of the distribution area (Topia, Potrero, Los

359 Herreras and Guanaceví) had larger sizes and higher spires in comparison with the

360 populations in the center (Progreso) and south (Las Peñas and El Salto) of the

361 distribution area (Table 5). The percentage of variance explained by the first three

362 phylogenetic components was $99.47 \%$ for the means of the linear variables, $99.98 \%$ for

363 the centroid size and $91.84 \%$ for the average shape obtained from the analysis of the

364 geometric morphometrics. Finally, the redundancy analysis obtained from the analysis

365 of the first three phylogenetic components was statistically significant $(P<0.05)$. The

366 bioclimatic variables associated with each dataset were different, although in all cases,

367 they were exclusively temperature variables, with the temperature annual range (Bio 7)

368 being the only common variable (Fig. 2). Although it was difficult to establish a pattern,

369 the data retrieved from geometric morphometric analysis allowed us to suggest that 
370 larger shells with higher spirals are related to the max temperature of the warmest

371 month (Bio 5), while smaller shells with the lower spirals were related to the temperature

372 annual range (Bio 7) and mean temperature of the wettest quarter (Bio 8) (Fig. 2).

373 Additional support for the aforementioned results proceed from the analysis of the

374 deformation grids in the phylomorphospace, where the populations located to the North

375 (Guanaceví, Los Herreras, Topia and Potrero) tend to have higher spires and higher

376 values of whorl expansion ratio that lead to squared shells, in contrast, the lower spires

377 and the lower values of whorl expansion ratio in the Center (Progreso) and South ( EI

378 Salto and Las Peñas) populations lead to wider an more rounded shells (Fig 3).

379 Discussion

380 Effects of the landscape on functional connectivity

381 The functional connectivity in terrestrial snails was determined by the availability

382 of microhabitats suitable for dispersal. Our findings showed that the variables related to

383 the humidity and relative aridity of the terrain, as well as the precipitation of the driest

384 and the wettest month, had a greater contribution to the potential distribution model

385 generated by Maxent. These variables were related to the apparent rupture of the

386 estivation period in May and to the period of activity and dispersion between July and

387 September, as has been suggested for other members of the group (Baur 1986; Aubry

388 et al. 2006). However, the climate component defined through the environmental

389 suitability analysis with the MAXENT maximum entropy algorithm and by the method

390 proposed by Noguerales et al. (2016) did not contribute significantly to explaining the

391 functional connectivity of $H$. durangoensis populations.

392 A possible explanation for this phenomenon might be related to the spatial

393 resolution provided by the bioclimatic layers. It has been demonstrated that the

394 geographic patterns of the areas of environmental suitability in the terrestrial mollusks

395 were particularly dependent on the resolution of the grid, since this increases or

396 diminishes the heterogeneity of the geographic space (Kadmon and Heller 1998).

397 However, the models generated for land snails at a resolution of 30 arc-seconds (1

$398 \mathrm{~km}^{2}$ ), as used in this study, have been shown to be efficient in explaining the historical

399 demographic reductions that are the consequence of contractions in the areas of

400 environmental suitability (Horsák et al. 2010; Pfenninger et al. 2014; Mumladze 2014; 
401 Patrao et al. 2015). In this sense, the areas of environmental suitability for $\mathrm{H}$.

402 durangoensis have decreased from $28.5 \%$ in the LGM to $17.6 \%$ at the present, a result 403 congruent with the population reductions recovered for this species with microsatellite 404 markers and DNA sequences (López et al. 2017; López et al. 2019). Therefore, 405 although the climate component apparently did not make a significant contribution to 406 functional connectivity, its influence on the taxon cannot be denied because $H$. 407 durangoensis likely experienced environmental tracking as a consequence of climate 408 change, as has been demonstrated in alpine populations of Arianta arbustorum (Baur 409 and Baur 2013).

410 On the other hand, the random forest algorithm has been shown to perform well 411 in predicting the current vegetation types in heterogeneous geographic areas, as it was 412 very robust in relation to the number of classes in which plant communities were 413 clustered, as has been verified by paleopalinological records for models generated for 414 LGM (Waske and Braun 2009; Rodriguez-Galiano et al. 2012; Vanselow and Samimi 415 2014; Hais et al. 2015). Thus, the results of efficiency in the assignment to plant 416 categories with the random forest algorithm (Table S1) fall within the values obtained in 417 other works (Waske and Braun 2009; Hais et al. 2015), suggesting that predictions of 418 vegetation cover in this study are correct. Although our paleovegetation maps apparently did not show significant changes in vegetation cover (Fig. S2), the resistance 420 results from Circuitscape suggested that these changes have occurred and that 421 resistance values have increased from the LGM to the present (Table 1). One of the 422 main limitations of analyses based on resistance surfaces is that the values assigned to 423 each of the categories are arbitrary; however, it has been shown that the assigned 424 resistance values have no effect on the habitat categories in a fragmented landscape 425 (Schweiger et al. 2004; Wang et al. 2008). Consequently, as has been reported for 426 other mountain snails (Schell and Hausdorf 2012; Hugall et al. 2002; Sherpa et al. 427 2018), the altitudinal displacement of plant communities in mountainous regions during 428 Quaternary climate changes could explain the dynamics of functional connectivity in $\mathrm{H}$. 429 durangoensis as has been postulated for other species distributed in the SMOc 430 (Metcalfe et al. 2000; Anducho-Reyes et al. 2008; Bryson et al. 2011; López-González 431 et al. 2014), 
Based on these findings, we hypothesized that the functional connectivity of $H$.

433 durangoensis on different temporal scales has been promoted by the presence of both

434 temperate and cold temperate forests and that two patterns can be distinguished as has

435 been suggested in Helix aspersa and Cepaea nemoralis (Arnaud et al. 2003; Schweiger

436 et al. 2004; Barahona-Segovia et al. 2019), for which two patterns can be distinguished.

437 The first is a model of isolation by distance on a larger geographic scale (Pfenninger

438 and Posada 2002; Arnaud et al. 2003; Schweiger et al. 2004), and the second is

439 possible dynamic metapopulation promoted both by environmental and landscape

440 heterogeneity on a fine geographic scale, as has been documented for other land snails

441 (Arnaud et al. 2001; Baur and Baur 2013).

442 Variation of the shell in H. durangoensis

443 The relationship between shell size and shape in land snails with climatic variables of

444 temperature and precipitation has been widely studied and is well known (see review in

445 Goodfriend 1986). However, while the effect of the genetic component on shell shape

446 variation has been studied (Goodacre 2001; Dowle et al. 2015; Sherpa et al. 2018), few

447 studies have attempted to control this effect (Webster et al. 2012; Kotsakiozi et al.

448 2013), and none so far have evaluated this effect at the intraspecific level. Our findings

449 showed, after controlling for the genetic effects, that the shell size and shape were

450 determined by climatic variables of temperature and precipitation (Fig. 2). However,

451 whereas these variables were not significant to explain the genetic relationships among

452 the groups, they suggested that both the phenotype and genotype were the results of

453 independent processes (Haase and Misof 2009); that is, the microhabitat conditions had

454 a great effect on the shell despite the existence of gene flow (Chiba and Davison 2007;

455 Fiorentino et al. 2013; Stankowski 2013; Proćków et al. 2017). Thus, whereas it has

456 been suggested that the use of comparative phylogenetic methods at intrapopulation

457 levels may generate poor informative results (Niewiarowski et al. 2004), the power of

458 resolution of these methods may depend on the taxon and the assessed trait (Martins

459 and Housworth 2002), as has been found in this study.

$460 \quad$ In addition, our results suggested that populations with larger shells and

461 apertures are distributed to the north, while populations with smaller shells and

462 apertures were distributed to the south. The altitudinal interval of the sampled localities 
463 in the northern region $(1,702-2,400 \mathrm{~m}$ asl $)$ was lower than the altitudinal interval in which 464 the populations in the southern region were collected (2,587-2,759 $\mathrm{m}$ asl), which was 465 consistent with the results previously found in intrapopulation studies of the species of 466 the genera Arianta, Vestia and Trochulus (Burla and Stahel 1983; Baur and Raboud 467 1988; Sulikowska-Drozd 2001; Proćków

468 et al. 2017), where the populations from colder climates had smaller shells. This could 469 be related to a greater probability of survival of organisms with small shells in 470 unfavorable climatic conditions (Baur et al. 2014) and the greater resistance to 471 crystallization temperatures (Ansart et al. 2014). At the same time, at higher altitudes, 472 the duration of individual growth time is shorter (Anderson et al. 2007; Proćków et al. 473 2017). However, there were also differences in the sizes of the aperture and the heights 474 of the spires between the north and south regions. These shells attributes could reflect 475 microclimatic conditions, where small apertures tended to occur in the drier and higher 476 altitude regions, meanwhile large apertures and higher spires occured at lower altitudes 477 as has been reported in other species (Anderson et al. 2007; Haase and Misof 2009; 478 Dowle et al. 2015).

479 How many ESUs?

480 In the literature, only two published works that addressed the definition of the ESUs of 481 land snails have been published (Holland and Hadfield 2002; Ursenbacher et al. 2010); 482 however, they did not remove the phylogenetic effects, which impacted their results. In 483 the first study, a fragment of the mtCOI DNA was used and only the phylogenetic trees, 484 genetic distances and AMOVA analysis in the 12 populations of the tree snail 485 Achatinella mustelina were recognized as six ESUs that were reproductively isolated 486 and distributed throughout a longitudinal transect of $24 \mathrm{~km}$ (Holland and Hadfield 2002). 487 In the second study, which used microsatellite loci and performed a genetic structure 488 analysis, two main clusters were found in Trochulus aureatus, although the authors 489 decided to define each one of the nine sampled populations as different ESUs, even 490 though they were separated by less than 200 meters (Ursenbacher et al. 2010). In 491 opposition, our results suggest that each of the seven genetic groups previously 492 identified by the analysis performed by López et al. (2017) must be considered an ESU, 493 not only because of their genetic distinctiveness but also due to the phenotypical 
494 differences. The removal of the phylogenetic effect shows that temperature and 495 precipitation variables were strong determinants of the shell size and shape of the 496 species, which explained the morphological differentiation (Fig. 2).

497 Conclusions

498 The main conclusion of this work is that vegetation cover has a high impact on the 499 functional connectivity of the land snail, as does climate, which is a strong determinant 500 of shell shape in this species. Previous studies have found that young restored forests 501 can achieve even higher snail diversities than old unperturbed forests (Hylander et al. 502 2004; Ström et al. 2009), although this could depend on survival in microrefugia or 503 dispersal from other patches. Forestry is one of the main economic activities in the state 504 of Durango, Mexico, that exerts strong pressure on the populations of the land snail $H$. 505 durangoensis due to habitat loss and degradation. Nevertheless, the development of 506 comprehensive management plans for the state (Conafor 2006) could guarantee the 507 long-term survival of $H$. durangoensis, although further studies need to be performed to 508 evaluate the potential effects of global climate warming on the species.

\section{Acknowledgments}

510 This work was funded by the Consejo Nacional de Ciencia y Tecnología project

511 number 165990. We also thank Angus Davison and two anonymous reviewers for their 512 comments.

\section{References}

516 Adams D, Collyer M, Kaliontzopoulou A (2019) Geometric Morphometric Analyses of 517 2D/3D Landmark Data.

518

Anderson TK, Weaver KF, Guralnick RP (2007) Variation in adult shell morphology and

520 life-history traits in the land snail Oreohelix cooperi in relation to biotic and abiotic

521 factors. J Mollus Stud 73:129-137. https://doi.org/10.1093/mollus/eym006 
523 Anducho-Reyes MA, Cognato Al, Hayes JL, Zúñiga G (2008) Phylogeography of the 524 bark beetle Dendroctonus mexicanus Hopkins (Coleoptera: Curculionidae: Scolytinae).

525 Mol Phylogenet Evol 49:930-940. https://doi.org/10.1016/j.ympev.2008.09.005

526

527 Ansart A, Guiller A, Moine O, Martin MC, Madec L (2014) Is cold hardiness size-

528 constrained? A comparative approach in land snails. Evol Ecol 28:471-493.

529 https://doi.org/10.1007/s10682-013-9680-9

530

531 Aragón-Piña EE, Garza-Herrera A, González-Elizondo MS, Luna-Vega I (2010)

532 Composición y estructura de las comunidades vegetales del rancho El Durangueño, en

533 la Sierra Madre Occidental, Durango, México. Rev Mex Biodivers 81:771-787.

534 http://www.scielo.org.mx/scielo.php?script=sci_arttext\&pid=S1870-

$53534532010000300018 \&$ lng $=$ es\&tlng=es

536

537 Armbruster GF, Hofer M, Baur B (2007) Effect of cliff connectivity on the genetic

538 population structure of a rock-dwelling land snail species with frequent self-fertilization.

539 Biochem Syst Ecol 35:325-333. https://doi.org/10.1016/j.bse.2006.12.005

540

541 Arnaud JF, Madec L, Guiller A, Bellido A (2001) Spatial analysis of allozyme and

542 microsatellite DNA polymorphisms in the land snail Helix aspersa (Gastropoda:

543 Helicidae). Mol Ecol 10:1563-1576. https://doi.org/10.1046/j.1365-294X.2001.01292.x

544

545

546 Arnaud JF (2003) Metapopulation genetic structure and migration pathways in the land

547 snail Helix aspersa: influence of landscape heterogeneity. Landsc Ecol 18:333-346.

548 https://doi.org/10.1023/A:1024409116214

549

550 Aubry S, Labaune C, Magnin F, Roche P, Kiss L (2006) Active and passive dispersal of

551 an invading land snail in Mediterranean France. J Anim Ecol 75:802-813.

552 https://doi.org/10.1111/j.1365-2656.2006.01100.x

553 
554 Barahona-Segovia RM, Riveros-Díaz AL, Zaror S, Catalán R, Araya JF (2019) Shelter, 555 ecophysiology and conservation status of Plectostylus araucanus (Pulmonata:

556 Bothriembryontidae) in the fragmented Maulino Forest, central Chile. Rev Mex Biodivers

557 90:1-11. https://doi.org/10.22201/ib.20078706e.2019.90.2703

558

559 Barbet - Massin M, Jiguet F, Albert CH, Thuiller W (2012) Selecting pseudo - absences 560 for species distribution models: how, where and how many?. Methods Ecol Evol 3:327561 338. https://doi.org/10.1111/j.2041-210X.2011.00172.x

562

563 Barve N (2008) Tool for Partial-ROC ver. 1.0. Biodiversity Institute, Lawrence, Kansas 564

565 Barve N, Barve V, Jiménez-Valverde A, Lira-Noriega A, Maher SP, Peterson AT, 566 Villalobos $F(2011)$ The crucial role of the accessible area in ecological niche modeling 567 and species distribution modeling. Ecol Model 222:1810-1819.

568 https://doi.org/10.1016/j.ecolmodel.2011.02.011

569

570 Baur B (1986) Patterns of dispersion, density and dispersal in alpine populations of the

571 land snail Arianta arbustorum (L.)(Helicidae). Ecography 9:117-125.

572 https://doi.org/10.1111/j.1600-0587.1986.tb01200.x

573

574 Baur B, Raboud C (1988) Life history of the land snail Arianta arbustorum along an

575 altitudinal gradient. J Anim Ecol 57:71-87. https://www.jstor.org/stable/4764

576

577 Baur B, Baur A (2013) Snails keep the pace: shift in upper elevation limit on mountain

578 slopes as a response to climate warming. Can J Zool 91:596-599.

579 https://doi.org/10.1139/cjz-2013-0036

580

581 Baur B, Meier T, Baur A, Schmera D (2014) Terrestrial gastropod diversity in an alpine 582 region: disentangling effects of elevation, area, geometric constraints, habitat type and

583 land - use intensity. Ecography 37:390-401. https://doi.org/10.1111/j.1600-

$584 \quad \underline{0587.2013 .00312 . x}$ 
585

586 Bell RC, Parra JL, Tonione M, Hoskin CJ, Mackenzie JB, Williams SE, Moritz C (2010)

587 Patterns of persistence and isolation indicate resilience to climate change in montane

588 rainforest lizards. Mol Ecol 19:2531-2544. https://doi.org/10.1111/j.1365-

589 294X.2010.04676.X

590

591 Bjørnstad ON (2013) Package 'ncf': Spatial nonparametric covariance functions. R

592 package version 1.1-3. http://CRAN.R-project.org/package=ncf

593

594 Borcard D, Gillet F, Legendre P (2018) Numerical ecology with R. Springer, New York

595

596 Botta F, Eriksen C, Fontaine MC, Guillot G (2015) Enhanced computational methods for

597 quantifying the effect of geographic and environmental isolation on genetic

598 differentiation. Methods Ecol Evol 6:1270-1277. https://doi.org/10.1111/2041-

599 210X.12424

600

601 Breiman L (2001) Random forests. Mach Learn 45:5-32.

602 https://doi.org/10.1023/A:1010933404324

603

604 Bryson Jr RW, Murphy RW, Graham MR, Lathrop A, Lazcano D (2011) Ephemeral

605 Pleistocene woodlands connect the dots for highland rattlesnakes of the Crotalus

606 intermedius group. J Biogeogr 38:2299-2310. https://doi.org/10.1111/j.1365-

607 2699.2011.02565.x

608

609 Buria H, Stahel W (1983) Altitudinal variation in Arianta arbustorum (Mollusca,

610 Pulmonata) in the Swiss alps. Genetics 62:95-108.https://doi.org/10.1007/BF00116631

611

612 Caro TM, O' Doherty G (1999) On the use of surrogate species in conservation biology.

613 Cons Biol 19: 1821-1826. https://doi.org/10.1046\%2Fj.1523-1739.1999.98338.x

614 
615 Chiba S, Davison A (2007) Shell shape and habitat use in the North-west Pacific land 616 snail Mandarina polita from Hahajima, Ogasawara: current adaptation or ghost of 617 species past?. Biol J Linn Soc 91:149-159. https://doi.org/10.1111/j.1095-

$618 \quad 8312.2007 .00790 . x$

619

620 CONAFOR (2006) Programa estrátegico forestal Durango.

621 http://www.conafor.gob.mx:8080/documentos/docs/12/177Programa\%20Estrat\%c3\%a9

622 gico\%20Forestal\%20de\%20Durango.pdf

623

624 Crandall KA, Bininda-Emonds OR, Mace GM, Wayne RK (2000) Considering

625 evolutionary processes in conservation biology. Trends Ecol Evol 15:290-295.

626 https://doi.org/10.1016/S0169-5347(00)01876-0

627

628 Cuttelod A, Seddon M, Neubert E (2011) European red list of non-marine molluscs.

629 Publication office of the European Union. Luxembourg, Publications Office of the

630 European Union

631

632 Davison A, Chiba S (2006) Labile ecotypes accompany rapid cladogenesis in an 633 adaptive radiation of Mandarina (Bradybaenidae) land snails. Biol J Linn Soc 88:269634 282. https://doi.org/10.1111/j.1095-8312.2006.00624.x

635

636 Dépraz A, Cordellier M, Hausser J, Pfenninger M (2008) Postglacial recolonization at a 637 snail's pace (Trochulus villosus): confronting competing refugia hypotheses using model 638 selection. Mol Ecol 17:2449-2462. https://doi.org/10.1111/j.1365-294X.2008.03760.x 639

640 Dörge N, Walther C, Beinlich B, Plachter H (1999) The significance of passive transport 641 for dispersal in terrestrial snails (Gastropoda, Pulmonata). Z Ökol Nat schutz 8:1- 10. 642

643 Dowle EJ, Morgan - Richards M, Brescia F, Trewick SA (2015) Correlation between 644 shell phenotype and local environment suggests a role for natural selection in the 
645 evolution of Placostylus snails. Mol Ecol 24:4205-4221.

646 https://doi.org/10.1111/mec.13302

647

648 Edworthy AB, Steensma KMM, Zandberg HM, Lilley PL (2012) Dispersal, home-range 649 size, and habitat use of an endangered land snail, the Oregon forestsnail (Allogona 650 townsendiana). Can J Zool 90:875-884. https://doi.org/10.1139/z2012-056

651

652 Elith JH, Graham CP, Anderson R, Dudík M, Ferrier S, Guisan A, Li J (2006) Novel 653 methods improve prediction of species' distributions from occurrence data. Ecography 654 29:129-151. https://doi.org/10.1111/j.2006.0906-7590.04596.x

655

656 Fahrig L (2003) Effects of habitat fragmentation on biodiversity. Annu Rev Ecol Evol 657 Syst 34:487-515. https://doi.org/10.1146/annurev.ecolsys.34.011802.132419

658

659 Fiorentino V, Manganelli G, Giusti F (2008) Multiple scale patterns of shell and anatomy 660 variability in land snails: the case of the Sicilian Marmorana (Gastropoda: Pulmonata, 661 Helicidae). Biol J Linn Soc 93:359-370. https://doi.org/10.1111/j.1095-

$662 \quad 8312.2007 .00940 . x$

663

664 Fiorentino V, Manganelli G, Giusti F, Tiedemann, R, Ketmaier V (2013) A question of 665 time: the land snail Murella muralis (Gastropoda: Pulmonata) reveals constraints on 666 667 668 669

Fitzpatrick BM (2012) Estimating ancestry and heterozygosity of hybrids using 670 molecular markers. BMC Evol Biol 12:131. https://doi.org/10.1186/1471-2148-12-131

671 Fraser DJ, Bernatchez L (2001) Adaptive evolutionary conservation: towards a unified 672 concept for defining conservation units. Mol Ecol 10:2741-2752.

673 https://doi.org/10.1046/j.0962-1083.2001.01411.x 
676 González-Elizondo MS, González-Elizondo M, Ruacho-González L, López-Enríquez IL, 677 Renata-Rentería FI, Tena-Flores JA (2013) Ecosystems and diversity of the Sierra 678 Madre Occidental. In: Merging science and management in a rapidly changing world: 679 Biodiversity and management of the Madrean Archipelago III and 7th Conference on 680 Research and Resource Management in the Southwestern Desert, 2012 May 1-5, 681 Tucson, AZ (Gottfried GJ, Ffolliott P F, Gebow BS, Eskew LG, Collins LC, eds) Fort 682 Collins, CO: US Department of Agriculture, Forest Service, Rocky Mountain Research 683 Station. pp. 204-211

684 685

Goodacre SL (2001) Genetic variation in a Pacific land snail: population history versus 686

687 current drift and selection. Proc R Soc B 268: 121-126 https://doi.org/10.1098/rspb.2000.1339

688 689

690

Goodfriend G A (1986) Variation in land-snail shell form and size and its causes: a 691 review. Syst Biol 35:204-223. https://doi.org/10.1093/sysbio/35.2.204

692

693

Guiller A, Madec L (2010) Historical biogeography of the land snail Cornu aspersum: a 694 new scenario inferred from haplotype distribution in the Western Mediterranean basin. BMC Evol Biol 10:1-18. https://doi.org/10.1186/1471-2148-10-18

Haase M, Misof B, Wirth T, Baminger H, Baur B (2003) Mitochondrial differentiation in a 698 polymorphic land snail: evidence for Pleistocene survival within the boundaries of permafrost. J Evol Biol 16:415-428. https://doi.org/10.1046/j.1420-9101.2003.00542.x Haase M, Misof B (2009) Dynamic gastropods: stable shell polymorphism despite gene flow in the land snail Arianta arbustorum. J Zool Syst Evol Res 47:105-114.

702 https://doi.org/10.1111/j.1439-0469.2008.00488.x

703

704 Hais M, Komprdová K, Ermakov N, Chytrý M (2015) Modelling the last glacial maximum 705 environments for a refugium of Pleistocene biota in the Russian Altai Mountains, 
706 Siberia. Palaeogeogr Palaeoclimatol Palaeoecol 438:135-145.

707 https://doi.org/10.1016/j.palaeo.2015.07.037

708

709

710

Hartigan JA, Wong MA (1979) Algorithm AS 136: A k-means clustering algorithm. J R

711

Stat Soc. Series C (Applied Statistics) 28:100-108. https://www.jstor.org/stable/2346830

712 Hernandez PA, Graham CH, Master LL, Albert DL (2006) The effect of sample size and

713 species characteristics on performance of different species distribution modeling

714 methods. Ecography 29:773-785. https://doi.org/10.1111/j.0906-7590.2006.04700.x

715

716 Heikkinen RK, Luoto M, Araújo MB, Virkkala R, Thuiller W, Sykes MT (2006) Methods

717 and uncertainties in bioclimatic envelope modelling under climate change. Prog Phys

718 Geog 30:751-777. https://doi.org/10.1177/0309133306071957

719

720 Hijmans RJ, Cameron SE, Parra JL, Jones PG, Jarvis A (2005) Very high resolution

721 interpolated climate surfaces for global land areas. Int J Climatol 25:1965-1978.

722 https://doi.org/10.1002/joc.1276

723

724 Hijmans RJ (2017) Raster: geographic analysis and modeling with raster data. R

725 Package versión 2.6-7.

https://CRAN.R-project.org/package=raster

726

727 Holland BS, Hadfield MG (2002) Islands within an island: phylogeography and

728 conservation genetics of the endangered Hawaiian tree snail Achatinella mustelina. Mol

729 Ecol 11:365-375. https://doi.org/10.1046/j.1365-294X.2002.01464.x

730

731 Holland BS, Cowie RH (2007) A geographic mosaic of passive dispersal: population

732 structure in the endemic Hawaiian amber snail Succinea caduca (Mighels, 1845). Mol

733 Ecol 16:2422-2435. https://doi.org/10.1111/j.1365-294X.2007.03246.x 
735 Horsák M, Chytrý M, Pokryszko BM, Danihelka J, Ermakov N, Hájek M, Lustyk P (2010)

736 Habitats of relict terrestrial snails in southern Siberia: lessons for the reconstruction of

737 palaeoenvironments of full-glacial Europe. J Biogeogr 37:1450-1462.

738 https://doi.org/10.1111/j.1365-2699.2010.02280.x

739

740

741 Hylander K, Nilsson C, Gunnar Jonsson B, Göthner T (2005) Differences in habitat

742 quality explain nestedness in a land snail meta - community. Oikos 108:351-361.

743 https://doi.org/10.1111/j.0030-1299.2005.13400.x

744

745 Hylander K, Nilsson C, Göthner T (2004) Effects of buffer - strip retention and

746 clearcutting on land snails in boreal riparian forests. Conserv Biol 18:1052-1062.

747 https://doi.org/10.1111/j.1523-1739.2004.00199.x

748

749 Hugall A, Moritz C, Moussalli A, Stanisic J (2002) Reconciling paleodistribution models 750 and comparative phylogeography in the Wet Tropics rainforest land snail Gnarosophia 751 bellendenkerensis (Brazier 1875). Proc Natl Acad Sci 99:6112-6117.

752 https://doi.org/10.1073/pnas.092538699

753

754

755 INE-INEGI, (1997) Uso del suelo y vegetación, escala 1:250000, serie I (continuo

756 nacional), escala: 1:250000. Instituto Nacional de Ecología - Dirección Ordenamiento

757 Ecológico Nacional e Instituto de Estadística, Geografía e Información. Digitalización de

758 las cartas de uso de suelo y vegetación elaboradas por INEGI entre los años 1980-

7591991 con base en fotografías aéreas de 1968-1986. México, D.F.

760 http://www.conabio.gob.mx/informacion/metadata/gis/usv250kcs1agw.xml? httpcache=

761 yes\& xsl=/db/metadata/xsl/fgdc html.xsl\& indent=no. Accessed 9 January 2019

762

763 Kadmon R, Heller J (1998) Modelling faunal responses to climatic gradients with GIS:

764 land snails as a case study. J Biogeogr 25:527-539. https://doi.org/10.1046/j.1365-

$765 \quad 2699.1998 .2530527 . x$ 
766

767 Kappes H, Jordaens K, Hendrickx F, Maelfait JP, Lens L, Backeljau T (2009) Response

768 of snails and slugs to fragmentation of lowland forests in NW Germany. Landsc Ecol

769 24:685-697. https://doi.org/10.1007/s10980-009-9342-z

770

771 Kistner EJ, Dybdahl MF (2013) Adaptive responses and invasion: the role of plasticity

772 and evolution in snail shell morphology. Ecol Evol 3:424-436.

773 https://doi.org/10.1002/ece3.471

774

775 Kotsakiozi P, Rigal F, Valakos ED, Parmakelis A (2013) Disentangling the effects of

776 intraspecies variability, phylogeny, space, and climate on the evolution of shell

777 morphology in endemic Greek land snails of the genus Codringtonia. Biol J Linn Soc

778 110:796-813. https://doi.org/10.1111/bij.12169

779

780 Labaune C, Magnin F (2002) Pastoral management vs land abandonment in

781 Mediterranean uplands: impact on land snail communities. Glob Ecol Biogeogr 11:237-

782 245. https://doi.org/10.1046/j.1466-822X.2002.00280.x

783

784

785 López B, Gómez R, Mejía O (2017) Strong genetic structure and signs of population

786 bottlenecks in the land snail Humboldtiana durangoensis in the Sierra Madre Occidental

787 of Western Mexico. J Zool Syst Evol Res 55:288-297. https://doi.org/10.1111/jzs.12177

788

789 López B, Zúñiga G, Mejía O (2019) Phylogeographic structure in the apparent absence

790 of barriers: a case study of the Mexican land snail Humboldtiana durangoensis

791 (Pulmonata: Humboldtianidae). J Molluscan Stud 85:244-252.

792 https://doi.org/10.1093/mollus/eyz007

793

794 López-González C, Correa-Ramírez MM, García-Mendoza DF (2014) Phylogeography

795 of Peromyscus schmidlyi: an endemic of the Sierra Madre Occidental, Mexico. J

796 Mammal 95: 254-268. https://doi.org/10.1644/13-MAMM-A-166 
797

798 Macías-Rodríguez MÁ, Giménez de Azcárate-Cornide J, Gopar-Merino LF (2017)

799 Sistematización bioclimática de la Sierra Madre Occidental (México) y su relación con

800 los pisos de vegetación. Polibotanica 1:125-163.

801 http://dx.doi.org/10.18387/polibotanica.43.6.

802

803 Manel S, Schwartz MK, Luikart G, Taberlet P (2003) Landscape genetics: combining

804 landscape ecology and population genetics. Trends Ecol Evol 18:198-197.

805 https://doi.org/10.1016/S0169-5347(03)00008-9

806

807

Martins EP, Housworth EA (2002) Phylogeny shape and the phylogenetic comparative

808 method. Syst Biol 51:873-880. https://doi.org/10.1080/10635150290102573

809

810

811

812

813

McRae BH (2006) Isolation by resistance. Evolution 60:1551-1561.

814 https://doi.org/10.1111/j.0014-3820.2006.tb00500.x

815

816

817

McRae BH, Dickson BG, Keitt TH, Shah VB (2008) Using circuit theory to model

818

connectivity in ecology, evolution, and conservation. Ecology 89:2712-2724.

https://doi.org/10.1890/07-1861.1

819

820

Mejía O, Zuniga G (2007) Phylogeny of the three brown banded land snail genus

821

Humboldtiana (Pulmonata: Humboldtianidae). Mol Phylo Evol 45:587-595.

822 https://doi.org/10.1016/j.ympev.2007.07.013

823

824 Mejía O, López B, Reyes-Gomez JP (2018) Three new species of the genus

825 Humboldtiana (Gastropoda: Pulmonata: Humboldtianidae) from Mexico. Nautilus

826 132:124-130.

827 
828

829 Metcalfe SE, O'Hara SL, Caballero M, Davies SJ (2000) Records of Late Pleistocene-

830 Holocene climatic change in Mexico_a review. Quaternary Sci Rev 19:699-721.

831 https://doi.org/10.1016/S0277-3791(99)00022-0

832

833 Mosimann JE (1970) Size allometry: size and shape variables with characterizations of 834 the lognormal and generalized gamma distributions. J Am Stat Assoc 65:930-945.

835

836

Mumladze L, Tarkhnishvili D, Murtskhvaladze M (2013) Systematics and evolutionary

837 history of large endemic snails from the Caucasus (Helix buchii and H. goderdziana)

838 (Helicidae). Am Malacol Bull 31:225-235. https://doi.org/10.4003/006.031.0202

839

840 Mumladze L (2014) Sympatry without co-occurrence: exploring the pattern of

841 distribution of two Helix species in Georgia using an ecological niche modelling

842 approach. J Molluscan Stud 80:249-255. https://doi.org/10.1093/mollus/eyu045

843

844 Niewiarowski PH, Angilletta MJ, Leaché AD (2004) Phylogenetic comparative analysis

845 of life - history variation among populations of the lizard Sceloporus undulatus: an

846 example and prognosis. Evolution 58:619-633. https://doi.org/10.1111/j.0014-

$847 \quad$ 3820.2004.tb01684.x

848

849

850 Noguerales V, Cordero PJ, Ortego J (2016) Hierarchical genetic structure shaped by

851 topography in a narrow-endemic montane grasshopper. BMC Evol Biol 16:96.

852 https://doi.org/10.1186/s12862-016-0663-7

853

854 Oksanen J, Blanchet FG, Kindt R, Legendre P, MinchinPRO' , Hara RB, Wagner H

855 (2013) Vegan: Community Ecology Package. R package version, 2.

856 http://CRAN.Rproject.org/package=vegan

857 
858 Ortego J, Riordan EC, Gugger PF, Sork VL (2012) Influence of environmental

859 heterogeneity on genetic diversity and structure in an endemic southern Californian

860 oak. Mol Ecol 21:3210-3223. https://doi.org/10.1111/j.1365-294X.2012.05591.x

861

862 Patrao C, Assis J, Rufino M, Silva G, Jordaens K, Backeljau T, Castilho R (2015)

863 Habitat suitability modelling of four terrestrial slug species in the Iberian Peninsula

864 (Arionidae: Geomalacus species). J Molluscan Stud 81:427-434.

865 https://doi.org/10.1093/mollus/eyv018

866

867 Pfenninger M, Posada D (2002) Phylogeographic history of the land snail Candidula

868 unifasciata (Helicellinae, Stylommatophora): fragmentation, corridor migration, and

869 secondary contact. Evolution 56:1776-1788. https://doi.org/10.1111/j.0014-

$870 \quad$ 3820.2002.tb00191.x

871 Pfenninger M, Weigand A, Bálint M, Klussmann - Kolb A (2014) Misperceived invasion:

872 the Lusitanian slug (Arion lusitanicus auct. non - Mabille or Arion vulgaris

873 Moquin - Tandon 1855) is native to Central Europe. Evol Appl 7:702-713.

874 https://doi.org/10.1111/eva.12177

875

876 Phillips SJ, Anderson RP, Schapire RE (2006) Maximum entropy modeling of species

877 geographic distributions. Ecol Model 190:231-259.

878 https://doi.org/10.1016/j.ecolmodel.2005.03.026

879

880 Poelchau MF, Hamrick JL (2012) Differential effects of landscape - level environmental

881 features on genetic structure in three codistributed tree species in Central America. Mol

882 Ecol 21:4970-4982. https://doi.org/10.1111/j.1365-294X.2012.05755.x

883

884 Proćków M, Kuźnik-Kowalska E, Mackiewicz P (2017) The Influence of climate on shell 885 variation in Trochulus striolatus (C. Pfeiffer, 1828) (Gastropoda: Hygromiidae) and its 886 implications for subspecies taxonomy. Ann Zool 67:199-221.

887 https://doi.org/10.3161/00034541ANZ2017.67.2.002 
889 Revell LJ (2012) phytools: an R package for phylogenetic comparative biology (and 890 other things). Methods Ecol Evol 3:217-223. http://www.respond2articles.com/MEE/ 891

892 Revelle W. (2018) psych: Procedures for Personality and Psychological Research, 893 Northwestern University, Evanston, Illinois, USA, https://CRAN.R-

894 project.org/package=psych Version $=1.8 .12$.

895

896

897 Rodriguez-Galiano VF, Ghimire B, Rogan J, Chica-Olmo M, Rigol-Sanchez JP (2012)

898 An assessment of the effectiveness of a random forest classifier for land-cover

899 classification. ISPRS J Photogramm Remote Sens 67:93-104.

900 https://doi.org/10.1016/j.isprsjprs.2011.11.002

901

902 Rohlf FJ (2008) TPSdig, v. 2.12. NY: State University at Stony Brook 903

904 Ross TK (1999) Phylogeography and conservation genetics of the lowa Pleistocene 905 snail. Mol Ecol 8:1363-1373. https://doi.org/10.1046/j.1365-294x.1999.00696.x 906 907

Scheel BM, Hausdorf B (2012) Survival and differentiation of subspecies of the land 909 snail Charpentieria itala in mountain refuges in the Southern Alps. Mol Ecol 21:3794910 3808. https://doi.org/10.1111/j.1365-294X.2012.05649.x

911

912 Schweiger O, Frenzel M, Durka W (2004) Spatial genetic structure in a metapopulation 913 of the land snail Cepaea nemoralis (Gastropoda: Helicidae). Mol Ecol 13:3645-3655.

914 https://doi.org/10.1111/j.1365-294X.2004.02357.x

915

916 Sherpa S, Ansart A, Madec L, Martin MC, Dréano S, Guiller A (2018) Refining the 917 biogeographical scenario of the land snail Cornu aspersum aspersum: Natural spatial 
918 expansion and human-mediated dispersal in the Mediterranean basin. Mol Phylogenet

919 Evol 120:218-232. https://doi.org/10.1016/j.ympev.2017.12.018

920

921

922 Stankowski S (2013) Ecological speciation in an island snail: evidence for the parallel 923 evolution of a novel ecotype and maintenance by ecologically dependent postzygotic

924 isolation. Mol Ecol 22:2726-2741. https://doi.org/10.1111/mec.12287

925

926 Ström L, Hylander K, Dynesius M (2009) Different long-term and short-term responses

927 of land snails to clear-cutting of boreal stream-side forests. Biol Conserv 142:1580-

928 1587. https://doi.org/10.1016/j.biocon.2009.02.028

929 Sulikowska-Drozd A (2001) Shell variability in Vestia turgida (Rossmassler, 1836)

930 (Gastropoda, Clausiliidae) along an altitudinal gradient. Folia Malacol 9:73-81.

931 http://dx.doi.org/10.12657/folmal.009.010

932

933 Tang CQ, Dong YF, Herrando-Moraira S, Matsui T, Ohashi H, He LY, Yan HZ (2017)

934 Potential effects of climate change on geographic distribution of the Tertiary relict tree

935 species Davidia involucrata in China. Sci Rep 7:43822.

936 https://doi.org/10.1038/srep43822

937

938 Thompson FG (2006) Some landsnails of the genus Humboldtiana from Chihuahua and 939 western Texas. Fla Mus Nat Hist 46:61-98.

940

941 Thompson FG, Hulbert RC (2011) An annotated checklist and bibliography of the land

942 and freshwater snails of Mexico and Central America. Bull Fla Mus Nat Hist 50:1-299.

943

944 Tischendorf L, Fahrig, L. (2000). On the usage and measurement of landscape

945 connectivity. Oikos, 90: 7-19.https://doi.org/10.1034\%2Fj.1600-0706.2000.900102.x

946 
947 Title PO, Bemmels JB (2018) ENVIREM: an expanded set of bioclimatic and

948 topographic variables increases flexibility and improves performance of ecological niche

949 modeling. Ecography 41:291-307. https://doi.org/10.1111/ecog.02880

950

951 Ursenbacher S, Alvarez C, Armbruster GF, Baur B (2010) High population

952 differentiation in the rock-dwelling land snail (Trochulus caelatus) endemic to the Swiss

953 Jura Mountains. Conserv Genet 11:1265-1271. https://doi.org/10.1007/s10592-009-

954 9956-3

955

956 Vanselow K, Samimi C (2014) Predictive mapping of dwarf shrub vegetation in an arid

957 high mountain ecosystem using remote sensing and random forests. Remote Sens

958 6:6709-6726. https://doi.org/10.3390/rs6076709

959

960 Wang YH, Yang KC, Bridgman CL, Lin LK (2008) Habitat suitability modelling to

961 correlate gene flow with landscape connectivity. Landsc Ecol 23:989-1000.

962 https://doi.org/10.1007/s10980-008-9262-3

963

964 Waske B, Braun M (2009) Classifier ensembles for land cover mapping using

965 multitemporal SAR imagery. ISPRS J Photogramm Remote Sens 64:450-457.

966 https://doi.org/10.1016/j.isprsjprs.2009.01.003

967

968 Webster NB, Van Dooren TJ, Schilthuizen M (2012) Phylogenetic reconstruction and

969 shell evolution of the Diplommatinidae (Gastropoda: Caenogastropoda). Mol Phylogenet

970 Evol 63:625-638. https://doi.org/10.1016/j.ympev.2012.02.004

971

972

973 


\section{Table 1 (on next page)}

Pairwise comparison of Circuitscape

Pairwise comparison of the resistance values obtained with Circuitscape using the vegetation cover as resistance surface 
1

2

\begin{tabular}{|c|c|c|c|}
\hline Pair & LGM & $\begin{array}{c}\text { mid } \\
\text { Holocene }\end{array}$ & Current \\
\hline 1,2 & 209.87 & 308.20 & 305.42 \\
\hline 1,3 & 196.76 & 318.14 & 294.33 \\
\hline 1,4 & 169.83 & 227.74 & 226.22 \\
\hline 1,5 & 309.86 & 359.06 & 356.54 \\
\hline 1,6 & 428.33 & 507.67 & 518.36 \\
\hline 1,7 & 371.76 & 424.61 & 420.29 \\
\hline 2,3 & 235.52 & 357.59 & 334.44 \\
\hline 2,4 & 182.15 & 243.87 & 247.67 \\
\hline 2,5 & 284.65 & 341.65 & 344.16 \\
\hline 2,6 & 402.27 & 489.54 & 505.29 \\
\hline 2,7 & 345.54 & 406.29 & 407.04 \\
\hline 3,4 & 164.42 & 236.34 & 213.96 \\
\hline 3,5 & 308.73 & 377.72 & 352.35 \\
\hline 3,6 & 427.46 & 526.63 & 514.47 \\
\hline 3,7 & 370.94 & 443.65 & 416.48 \\
\hline 4,5 & 224.20 & 238.48 & 240.16 \\
\hline 4,6 & 343.37 & 387.74 & 402.65 \\
\hline 4,7 & 286.93 & 304.84 & 304.74 \\
\hline 5,6 & 209.67 & 251.50 & 264.47 \\
\hline 5,7 & 159.03 & 175.71 & 173.63 \\
\hline 6,7 & 162.45 & 227.27 & 239.57 \\
\hline \multicolumn{4}{|c|}{$\begin{array}{l}\text { The numbers in the first column correspond to the geographic } \\
\text { centroid of each one of the seven genetic groups recovered by } \\
\text { López et al. 2017: 1) Guanaceví 2) Los Herreras 3) Potrero 4) } \\
\text { Topia 5) Progreso 6) El Salto and 7) Las Peñas. }\end{array}$} \\
\hline
\end{tabular}

Table 1. Pairwise comparison of the resistance values obtained with Circuitscape using the vegetation cover as resistance surface

The numbers in the first column correspond to the geographic Lopez et at. 2017:1) Guanacevi 2) Los Hereras 3) Potrero 4) López et al. 2017: 1) Guanaceví 2) Los Herreras 3) Potrero 4) 


\section{Table 2 (on next page)}

Isolation by distance and resistance

Mantel partial test of the effect of isolation by distance (IBD) and isolation by resistance (IBR)

from climate and vegetation surfaces on the genetic differentiation of Humboldtiana durangoensis populations for the three temporal frames used in this study 
1 Table 2. Mantel partial test of the effect of isolation by distance (IBD) and isolation by 2 resistance (IBR) from climate and vegetation surfaces on the genetic differentiation of 3 Humboldtiana durangoensis populations for the three temporal frames used in this study.

\begin{tabular}{clccccccc}
\hline \multirow{2}{*}{ Resistance model } & \multicolumn{1}{c}{ Comparison } & \multicolumn{2}{c}{ LGM } & \multicolumn{2}{c}{ mid Holocene } & \multicolumn{2}{c}{ Current } \\
& & $\mathbf{R}$ & $\mathbf{p}$ & $\mathbf{R}$ & $\mathbf{p}$ & $\mathbf{R}$ & $\mathbf{p}$ \\
\hline \multirow{3}{*}{ Climate } & fst vs resistance & 0.474 & 0.094 & 0.368 & 0.122 & 0.418 & 0.111 \\
& fst vs geogra|resistance & 0.182 & 0.321 & 0.39 & 0.081 & 0.295 & 0.191 \\
& fst vs resistance |geogra & 0.105 & 0.398 & -0.181 & 0.362 & -0.074 & 0.476 \\
\multirow{3}{*}{ Vegetation } & fst vs resistance & 0.057 & 0.382 & -0.144 & 0.29 & -0.111 & 0.344 \\
& fst vs geogra|resistance & 0.782 & $\mathbf{0 . 0 0 5}$ & 0.796 & $\mathbf{0 . 0 0 3}$ & 0.784 & $\mathbf{0 . 0 0 9}$ \\
& fst vs resistance|geogra & -0.699 & $\mathbf{0 . 0 1 2}$ & -0.725 & $\mathbf{0 . 0 1 3}$ & -0.706 & $\mathbf{0 . 0 2 1}$ \\
\hline
\end{tabular}

$4 \quad \mathrm{R}=$ Spearman correlation coefficent between pairwise genetic distances $\left(\mathrm{F}_{\mathrm{ST}} /\left(1-\mathrm{F}_{\mathrm{ST}}\right)\right)$ and

5 the Euclidean distance from the geography and pairwise resistance of CIRCUITSCAPE.

$6 p=$ Statistical significance obtained from 1000 replicates. 


\section{Table 3(on next page)}

distance based redundance analysis

Effect of the geographic distance (IBD), vegetation and climate on the genetic differentiation among the seven genetic populations of Humboldtiana durangoensis obtained from the distance based redundance analysis ( $d b R D A$ ) for the three temporal frames used in this study 
1 Table 3. Effect of the geographic distance (IBD), vegetation and climate on the genetic 2 differentiation among the seven genetic populations of Humboldtiana durangoensis 3 obtained from the distance based redundance analysis (dbRDA) for the three temporal 4 frames used in this study

\begin{tabular}{lcccccc}
\hline & \multicolumn{2}{l}{ Marginal tests } & & \multicolumn{3}{c}{ Conditional tests } \\
Variable & $\mathbf{F}$ & $\mathbf{p}$ & $\mathbf{\%}$ var & $\mathbf{F}$ & $\mathbf{p}$ & \% var \\
\hline LGM & & & & & & 0 \\
Geographic & 6.086 & $\mathbf{0 . 0 2}$ & 24.26 & & $\mathbf{0 . 0 0 2}$ & 33.819 \\
Vegetation & 0.605 & 0.447 & 3.087 & 14.521 & 0.623 & 1.013 \\
PCA1 & 1 & 0.327 & 4.999 & 0.244 & 0.266 & 5.131 \\
PCA2 & 2.979 & $\mathbf{0 . 1}$ & 13.552 & 1.308 & 0.238 & 5.956 \\
PCA3 & 0.098 & 0.748 & 0.515 & 1.536 & & \\
mid Holocene & & & & & & 0 \\
Geographic & 6.086 & $\mathbf{0 . 0 2 6}$ & 24.26 & & $\mathbf{0}$ & 39.849 \\
Vegetation & 0.404 & 0.537 & 2.083 & 19.986 & $\mathbf{0 . 1 7 7}$ & 7.286 \\
PCA1 & 2.106 & 0.166 & 9.976 & 1.916 & 0.785 & 0.312 \\
PCA2 & 0.419 & 0.516 & 2.158 & 0.074 & 0.105 & 10.473 \\
PCA3 & 1.211 & 0.284 & 5.992 & 2.888 & & \\
Current & & & & & & \\
Geographic & 6.086 & $\mathbf{0 . 0 2 5}$ & 24.26 & & & \\
Vegetation & 0.235 & 0.636 & 1.224 & 17.844 & $\mathbf{6 . 0 0 E}-04$ & 37.704 \\
PCA1 & 0.408 & 0.525 & 2.101 & 0.138 & 0.704 & 0.578 \\
PCA2 & 2.095 & 0.161 & 9.933 & 1.723 & 0.213 & 6.617 \\
PCA3 & 1.48 & 0.231 & 7.228 & 2.82 & 0.108 & 10.258 \\
\hline
\end{tabular}

5 In the marginal test the effect of each one of the variables was evaluated separately, 6 meanwhile, in the conditional test, the effect of the geographic distance was included as 7 a covariate. $\mathrm{F}$ represent the proportion of variance, $\mathrm{p}$ the statistical significance and \% 8 var the percentage of variance explained from each variable 


\section{Table 4(on next page)}

Results of the Bayesian inference and model selection obtained from SUNDER

Results of the Bayesian inference and model selection obtained from SUNDER to evaluate the relative effect of geography and vegetation cover on the genetic differentiation of the seven genetic groups of Humboldiana durangoensis. 
1 Table 4. Results of the Bayesian inference and model selection obtained from SUNDER 2 to evaluate the relative effect of geography and vegetation cover on the genetic 3 differentiation of the seven genetic groups of Humboldiana durangoensis.

\begin{tabular}{lcccccccc}
\hline \multicolumn{1}{c}{ Period } & \multirow{2}{*}{ Iteration } & \multicolumn{2}{c}{ G } & \multicolumn{2}{c}{ E } & \multicolumn{3}{c}{ G+E } \\
& & Likelihood & Bg & Likelihood & Be & Likelihood & Bg & Be \\
\hline LGM & $(6,3,1)$ & -8975.22 & 4.13 & -9053.74 & 521.65 & -9044.04 & 4.15 & 1102.35 \\
mid & $(3,3,6)$ & -6712.19 & 3.29 & -6672.19 & 524.79 & -6638.51 & 3.52 & 2040.62 \\
Holocene & $(3,2,5)$ & -9942 & 3.63 & -9964.55 & 530.97 & -9890.39 & 3.29 & 1711.27 \\
Current & $(3,2)$
\end{tabular}

4 G: Euclidean geographic distances; E: Resistance values obtained for the vegetation 5 cover; G+E: combined effect of both variables. The numbers inside brackets in the 6 iteration column indicate the number of times that each one of the three models has 7 obtained the lower value of likelihood in ten independent runs. The parameter $\beta$ 8 represents the magnitude of the effect of the variable on the genetic covariance (lower 9 values indicate a more important effect). 


\section{Table 5 (on next page)}

Shell measurements performed

Average size (in $\mathrm{mm}$ ) for the four measurements used in this study to evaluate the shell shape of seven genetic groups of Humboldtiana durangoensis. Shell height (SH), Shell width $(\mathrm{SH})$ Aperture height (AH), Maximum Aperture width (AW). Additionally, Globosity index (G), Spire Height (SP) and Shell Volume are shown 
1 Table 5. Average size (in $\mathrm{mm}$ ) for the four measurements used in this study to evaluate 2 the shell shape of seven genetic groups of Humboldtiana durangoensis. Shell height $3 \mathrm{(SH})$, Shell width (SH) Aperture height ( $\mathrm{AH})$, Maximum Aperture width (AW). Additionally, 4 Globosity index (G), Spire Height (SP) and Shell Volume are shown

\begin{tabular}{lcccccccc}
\hline \multicolumn{1}{c}{ Group } & N & SH & SW & ALH & AW & G & SP & V \\
\hline Guanacevi & 20 & 32.15 & 34.45 & 21.66 & 19.52 & 0.93 & 10.49 & 3.42 \\
Los Herreras & 25 & 31.94 & 33 & 22.06 & 19.09 & 0.97 & 9.88 & 3.29 \\
Potrero & 46 & 32.86 & 35.4 & 22.32 & 20.34 & 0.93 & 10.54 & 3.47 \\
Topia & 7 & 31.13 & 32.56 & 23.18 & 18.98 & 0.96 & 7.95 & 3.22 \\
Progreso & 3 & 24.11 & 26.16 & 19.11 & 15.81 & 0.92 & 5 & 2.62 \\
El Salto & 8 & 28.94 & 31.3 & 21.28 & 17.97 & 0.93 & 7.66 & 3.16 \\
Las Peñas & 20 & 25.51 & 28.14 & 19.32 & 16.29 & 0.91 & 6.18 & 2.87 \\
\hline
\end{tabular}

5 


\section{Figure 1}

Study area used

Geographic map of the Region Madrense Centro in the Mexican state of Durango. A) A digital elevation model (DEM) was used to highlight the different ombrothermal horizons defined by Macías-Rodriguez et al. (2017). The circles represent the geographic centroid for each one of the seven genetic groups of Humboldtiana durangoensis defined from microsatellite markers in López et al. (2017): 1) Guanaceví 2) Los Herreras 3) Potrero 4)Topia 5) Progreso 6) El Salto and 7) Las Peñas. The deformation grids around the genetic groups represent the average shape of each one of the genetic groups. In the lower section a suitability distribution map from Maxent is showed for the three temporal frames used in this study assuming a minimum training presence from the model B) Last Glacial Maximum-LGM (0.172) C) Mid Holocene (0.369) and D) Current time (0.347) 


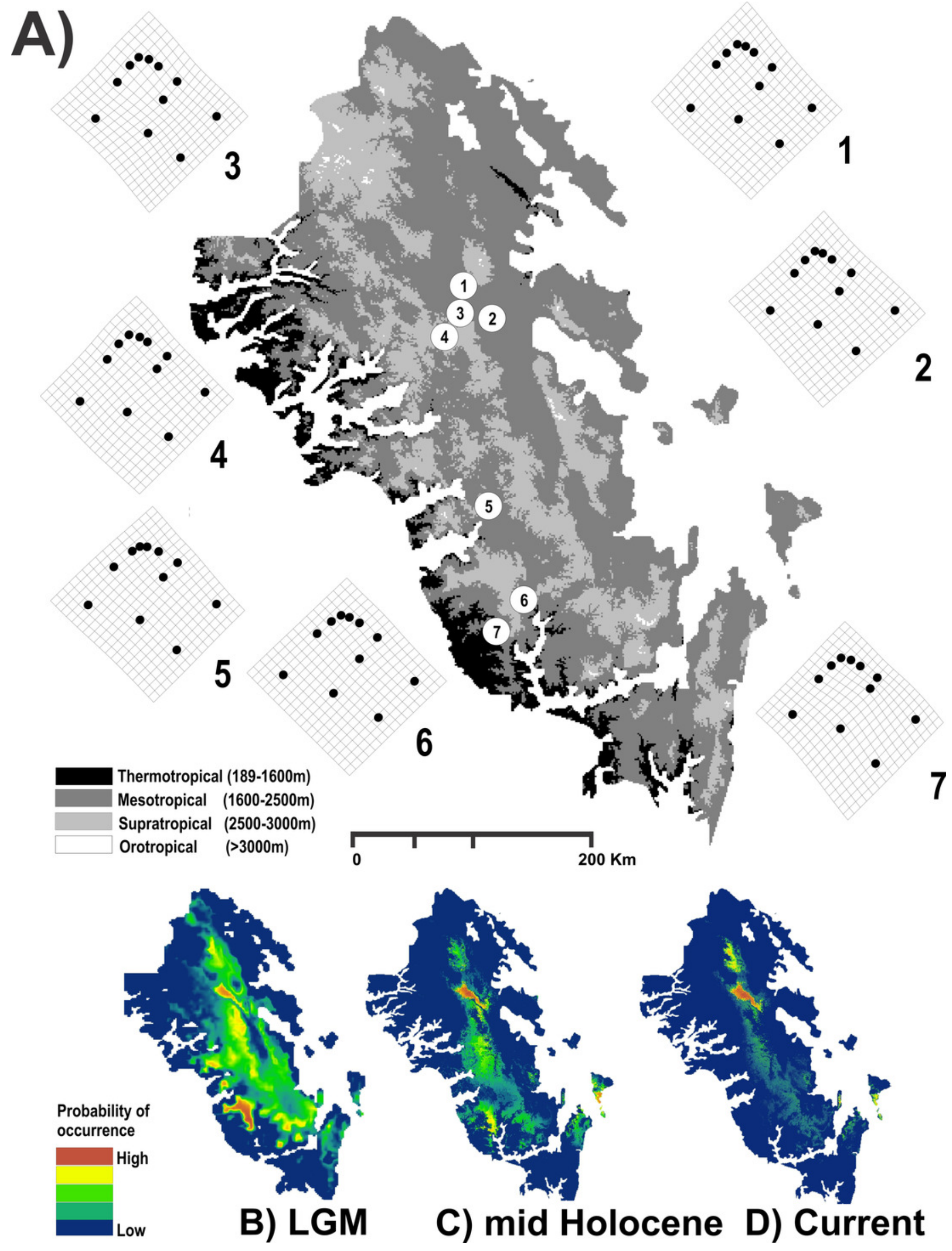




\section{Figure 2}

Redundancy analysis (RDA) for the shell shape

Redundancy analysis (RDA) for the shell shape of Humboldtiana durangoensis between: A) Average size from traditional morphometrics B) Centroid from traditional morphometrics C) Consensus shape from geometric morphometrics and climate variables from Worldclim. The direction and size of the arrows indicate the correlation between climate variables and RDA axes. The circles represent the geographic centroid for each one of the seven genetic groups: 1) Guanaceví 2) Los Herreras 3) Potrero 4)Topia 5) Progreso 6) El Salto and 7) Las Peñas 

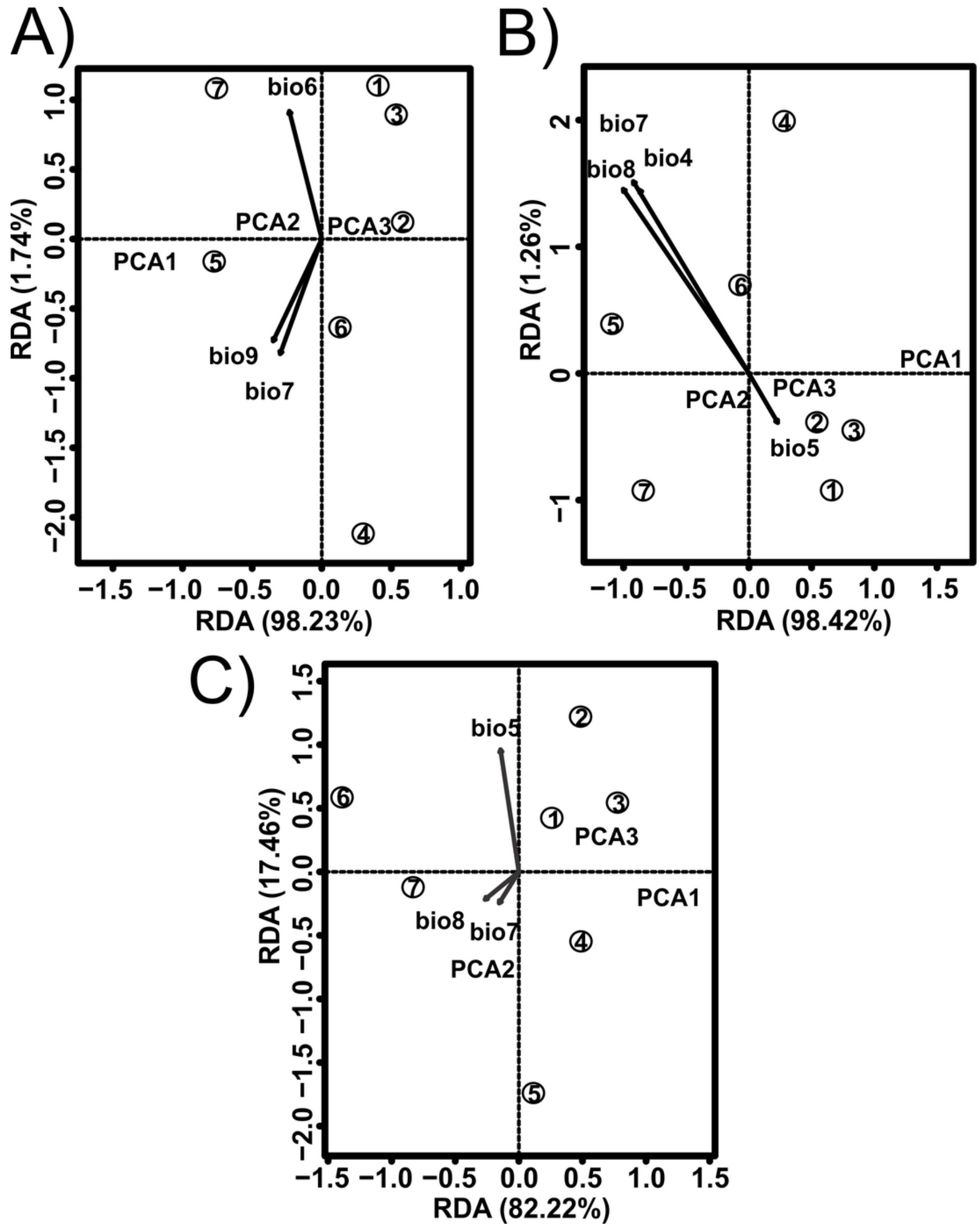


\section{Figure 3}

Deformation grids of shell shape

Deformation grids of the consensus shape of the shells of $H$. durangoensis plotted into the phylomorphospace. The black circles correspond to each one of the seven genetic groups analyzed. 1) Guanaceví 2) Los Herreras 3) Potrero 4) Topia 5) Progreso 6) El Salto and 7) Las Peñas. The first two components of the phylomorphospace explained $74.07 \%$ of the variation in shell shape 


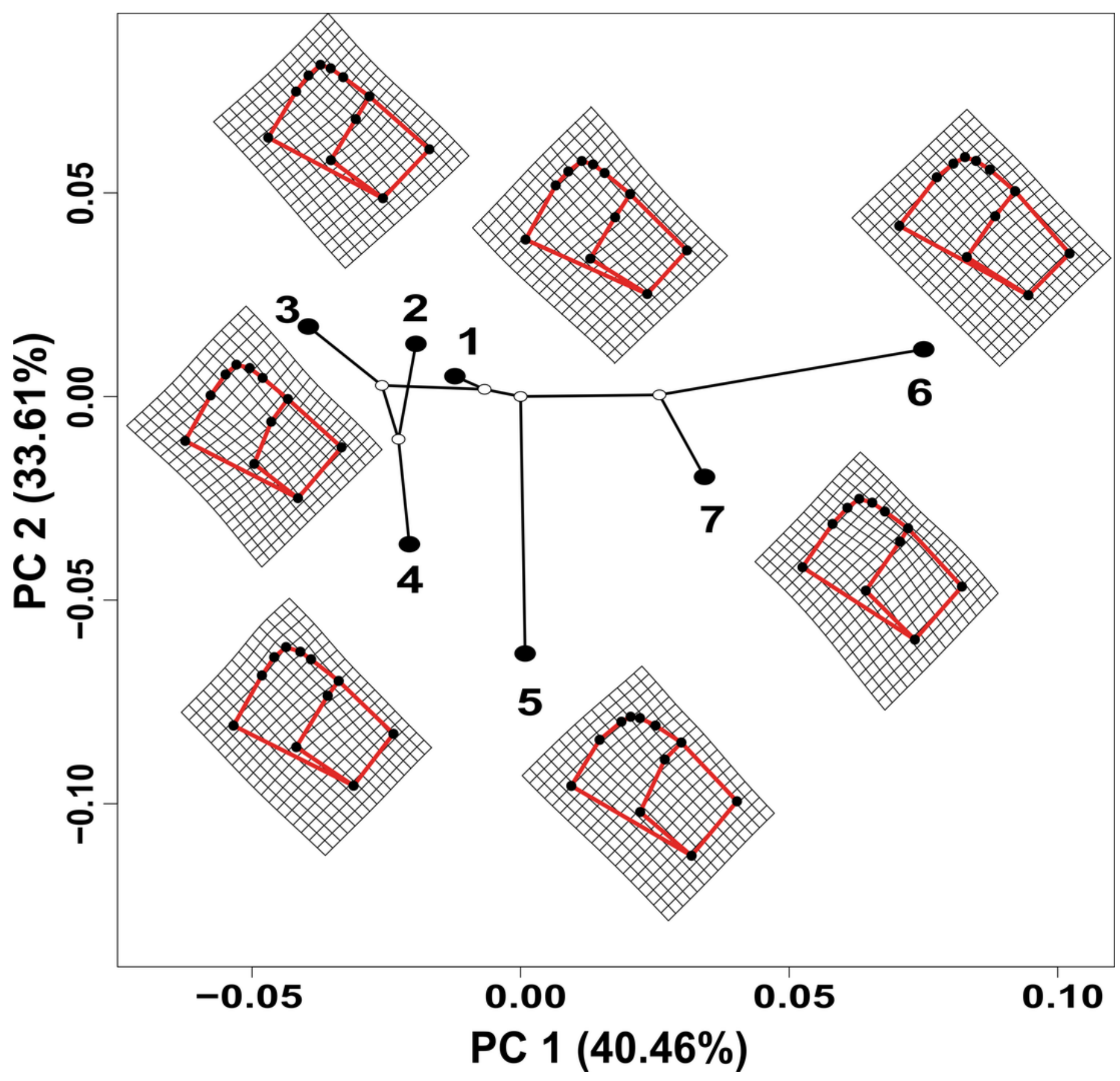

